\title{
Tax Dispute Analysis of Incorrect VAT Payment on Offshore Royalty viewed from the Ease of Administration Principle (Case Study of PT X)
}

\author{
Iman Santoso ${ }^{1}$, Mikha Grinelda Ningrum ${ }^{2}$, Milla Sepliana Setyowati ${ }^{3}$ \\ \{imansa1969@gmail.com¹, mikhagrinelda31@gmail.com², milla.s.setyowati@gmail.com ${ }^{3}$ \} \\ Department of Fiscal Administration, Faculty of Administration Science, University of Indonesia ${ }^{1,2,3}$
}

\begin{abstract}
The occurrence of selling and buying transactions cause every companies to do their VAT obligations. Tax reported by PT X which appear to be wrong can be subdued by overbooking, therefore PT X had to bear administrative sanctions. The purpose of this research is to analyze basic considerations from Directorate General of Taxes in making regulations regarding the incorrect transfer of Taxable Services from outside the custom territory which cannot be overbook and analyze whether the administrative sanctions given to taxpayer are appropriate, with Ease of Administration principle in deliberation. This research used a qualitative approach with in-depth interview and literature study for data collection. The result of this research concludes that the primary consideration Directorate General of Taxes made regulations concerning the incorrect transfer of Taxable Services from outside the customs territory is because Intangible Taxable Goods and Taxable Services from outside the customs territory are susceptible to being used by Taxpayers for the purpose of avoiding tax and the Government's control are not fully reliable. Because the regulations do not allow to do the overbook, alternative ways taken by PT X to resolve the incorrect transfer of tax is restitution, which causes administrative sanctions. With that being said, administrative sanctions that occur as a result of wrong transfer of tax do not fulfill the Ease of Administration principle.
\end{abstract}

Keywords: value added tax, royalty, intangible taxable goods; incorrect tax settlement; administrative sanctions; tax dispute; overbooking

\section{Introduction}

Cross-country transactions indirectly result in transactions between goods and / or services between countries. Each country needs and complement each other because basically each country has different characteristics, both in terms of natural resources, climate, geography, demography, economic structure and social structure. The differences in various aspects create differences in the commodities produced, so that the exchange of goods and / or services between countries is needed in a trade relationship [1]. According to the Ministry of Trade's data on exports and imports, it appears that import transactions have a higher number than exports from year to year.

In relation to taxation aspects, import transactions affect Value Added Tax (VAT). Import objects, which includes taxable goods (tangible and intangible) and taxable services outside the customs territory must be reported in VAT. In carrying out tax obligations usch as reporting taxes, it does not rule out the possibility of errors in the administrative stages. Some things that need to be considered in carrying out the taxation report start from the fulfillment classification of taxpayers as Taxable Enterprise, the deposit due date for each monthly tax 
return, recording VAT Transaction Type for each tax object reported, and every other element in the tax return.

Each of the existing provisions and rules is based on the Law No. 28/2007 concerning General Provisions and Tax Procedures (referred as Ketentuan Umum dan Tatacara Perpajakan (KUP)). Both of these objects can experience administrative errors that cause a wrong deposit but can not do overbooking as an alternative. PT X as the Domestic Taxpayer made a mistake to report royalties that were utilized from abroad, namely by Y Co., Ltd. as a taxable service outside the custom territory, which should be recorded as intangible taxable goods. This happens due to an error in the VAT Transaction Type being exchanged. The error or misrecording was not resolved administratively by overbooking, but instead became a tax dispute due to administrative sanctions. Based on the aforementioned background, the purpose of this paper is to analyze the considerations of the Directorate General of Taxation (DGT) to not do the overbooking on the misrecording of VAT between intangible taxable goods and taxable services outside the customs territory, and to analyze the administrative sanctions obtained by PT X related to tax disputes due to incorrect payment of the VAT object in the form of royalties in terms of the ease of administration principle.

\section{Literature Review}

\subsection{Value Added Tax}

The added value contained in VAT is the value arising from the application of the crediting method between VAT-Input on VAT-Output, which is used by Taxable Enterprise in collecting VAT which must be deposited to the State [2]. According to Sukardji in his book, there are several characteristics of the VAT, which can be specified as follows [3]: VAT are is a form of indirect tax, objective tax, and multistage tax; VAT calculated using the Indirect Subtraction Method / Credit Method / Invoice Method; and VAT is the domestic consumption tax, and classified as neutral.

\subsection{Intangible Taxable Goods and Taxble Services Outside the Customs Teirrtory}

The utilization of intangible taxable goods and taxable services outside the customs territory often done in Indonesia, where Indonesia adheres to the destination principle. According to Sukardji, the utilization of these two tax objects is the practice of the destination principle because these two objects originate from outside the customs territory but are consumed within the customs territory, that is Indonesia. Intangible taxable goods and taxable services outside the customs territory do not have a tangible form, so the treatment of tangible goods originating from outside the customs territory but utilized at the customs territory is certainly different. Tangible goods originating from outside the customs territory are identical to imports using import goods declarations as evidence and dealing with the Directorate General of Customs and Excise. Therefore, intangible taxable goods and taxable services from outside the customs territory do not use import goods declaration document as supporting documents.

\subsection{Principles of Taxation}

Principle is a basic concept that becomes a reference in taking any action. Similar to tax collection, there are principles that become the basis of reference in carrying out tax 
obligations. In particular, the principle of ease of administration where in tax collection, tax policy is needed to be efficient and effective in its implementation. The complicated rules that make taxpayers feel difficult to pay taxes will actually reduce taxpayer compliance. The most important principle that serves as a guideline for making taxation more efficient and effective is the Ease of Administration principles. As quoted in the "Pengantar Ilmu Pajak" by Rosdiana and Irianto, the principle of tax collection becomes certainty, efficiency, convenience and simplicity are made into one of the principles of ease of administration [4]:

1) Certainty: Subjects, objects, basis for taxation, tariffs, and procedures

This principle must include certainty regarding who should be taxed, what is classified as tax object and the amount of tax that must be paid. Along with that, this principle confirms that in taxation it must also have certainty in the procedure of fulfilling obligations including payment and reporting procedures to the implementation of the rights obtained by taxpayers. With the certainty of taxation, the level of compliance will certainly increase. [5]

2) Efficiency: On tax authorities' side: Administrative \& Enforcement Cost is relatively low, and on taxpayer' side: Compliance Cost is relatively low

The principle of efficiency means promoting efficiency in taxation both from the perspective of the tax authorities as tax collectors or from the taxpayer side as taxpayers. In the process of tax collection, of course costs are required from the State. Therefore, in terms of the tax authorities, it is said to be efficient if the cost of collecting taxes is lower than the amount of tax collected. In tax collection, of course the government sets aside the state money. Meanwhile, it is said to be efficient in terms of taxpayers if the costs incurred by taxpayers to fulfill their tax obligations can be as minimal as possible.

3) Convenience of Payment: Taxes are collected at the right time, determining the due date for payment of taxes, and payment procedures

The convenience principle emphasizes convenience or comfort in taxation activities. The principle of convenience states that the payment of taxes should be made possible when it is pleasant or easy for taxpayers. For example, taxes are collected when receiving salary, when receiving interest on deposits, or tax payments in installments so that taxpayers are not too heavy. [4]

4) Simplicity: easy to implement and not complex

Simplicity explains that the principle of taxation should be simple, clear and easily understood by taxpayers. This is important both for taxpayers and tax authorities because the tax authorities should also pay attention to tax policies that can be understood by taxpayers. The ease and simplicity of taxation is divided into the simplicity of the taxation system, the simplicity of tax law, the simplicity of taxpayer communication, and the simplicity of tax administration. The complexity of a tax policy will reduce the level of taxpayer compliance [6].

\section{Method}

In this study, a qualitative approach was used with the aim of conducting in-depth analysis related to tax disputes experienced by PT X relating to administrative sanctions received due to incorrect deposits. This type of research is a descriptive study, to explain the taxpayer dispute with the DGT because of objections from the taxpayers related to the payment of one of the objects of taxable services from outside the customs area. Based on the objection, it will 
be analyzed again on matters that make taxpayers feel disadvantaged by considering the fulfillment of the ease of administration principle. This research is an applied research, where this research arises from the practice that occurred in the field regarding disputes in the tax court which was carried out in the period June - December 2019.

In this study researcher used qualitative data collection techniques, through literature studies and field studies. This study uses taxation regulations that are assisted by regulations that apply in Indonesia, or books, journals, and articles related to topics related to this research, so that they can be linked to cases that occur. Field studies used for data collection in this study were conducted by conducting interviews with parties who understood the problem in the study, namely the Directorate of Taxation Regulations I of the DGT, Tax Policy and PBNP I Fiscal Policy Agency, Division of Research and Training Services at Danny Darussalam Tax Center (DDTC), Attorney at PT X, and tax policy expert academics. Data and information obtained from sources and literature studies were analyzed qualitatively by triangulating with related theories, VAT regulation, and expert opinions.

\section{Result And Discussion}

\subsection{Consideration of the DGT on the Overbook can not be made on the Mis recording of Depositing Taxable Services Outside the Customs Territory}

Overbook is one of the instruments provided by the DGT for Taxpayers in the case of when the taxpayer makes a mistake in carrying out his taxation obligations. Every Taxpayer has the right to use every instrument provided by the Government, especially Overbook which is considered to be one of the instruments that is quite simple. In the condition that there is an error in tax payment, and overbooking can be done in accordance with the rules set forth in Article 16 of Minister of Finance Regulation PMK 242 / PMK.03 / 2014 concerning Procedures for Payment and Depositing Taxes, then the Taxpayer can simply make a letter for overbook' request in accordance with the requirements and obligations. Furthermore, the DGT will then respond by issuing Proof of Overbook if all the requirements have been met or otherwise can issue Notification of Overbook Can Not Be Processed if it does not meet the requirements. Behind the things that are allowed for overbook, there are also some things that are not allowed in accordance with Article 16 Paragraph (9) in PMK 242 / PMK.03 / 2014, one of them is in letter b which states that Overbook cannot be carried out on: "Overbook to VAT payment for tax objects that must be paid by the Taxpayer himself using the Tax Payment Slip whose position is equivalent to the Tax Invoice". This confirms that intangible taxable goods and taxable services outside the customs territory cannot be done with overbook. Intangible taxable goods along with taxable services outside the customs territory are the objects of VAT which must be paid by the Taxpayer himself using the Tax Payment Slip. This is because the utilization of the intangible taxable goods and taxable services outside the customs territory comes from Foreign Taxpayers who are outside the customs territory so that they cannot collect the VAT. The basic considerations of the DGT in making those regulation which does not allow special overbooking for misuse utilization of intangible taxable goods and taxable services outside the customs territory can be described as follows:

1. Intangible taxable goods and taxable services outside the customs territory use proof of payment in the form of a Tax Payment Slip that is equivalent to a Tax Invoice. Whereas for conducting overbook, it means that there is a cancellation process for the referred Tax Payment Slip. The cancellation process is related to how the utilization of intangible 
taxable goods and / or taxable services outside the customs territory referred to. This certainly must go through a research process to confirm the cancellation so there is no utilization appears of the two objects. Cancellation of the utilization of the two objects is considered uncertain because the nature of the two objects must have been attached to the taxpayer who has used the object. Obviously, this is caused by characteristics of objects that are invisible and difficult to detect.

2. These intangible taxable goods and taxable services outside the customs territory use the Tax Payment Slip as document evidence. In this Tax Payment Slip, there is a column for Taxpayer Name and Taxpayer Identification Number to be completed by the Seller whereas in this case the seller is a foreign party. The data contained in Tax Payment Slip determines who is the owner of Tax Payment Slip, in other words in this case the owner of Tax Payment Slip is a foreign party that submits submission to PT X. In the case of conducting overbook, the party that can provide the application is the party whose name is written on the Tax Payment Slip data, in other words the owner of Tax Payment Slip. The owner of the deposit is Y Co., Ltd. as a foreign party that submits royalties to PT X. This will complicate the overbooking process because it involves a foreign party and approval from the foreign party. In addition to the difficulty of access from abroad to apply for overbooking, the Tax Payment Slip is also able to become one of the Taxpayer instruments to make fraud considering that the owner of Tax Payment Slip is a foreign party, so that Domestic Taxpayers who utilize the submission of this object can take actions that are detrimental to the state.

3. Taxes that have been deposited in the State treasury are not missing and have been paid. Existing tax payments can still be credited indicating that the money from the tax thas been deposited is not lost. The government has considered that there is no point on completing the overbooking, as long as the existing deposits can be credited. This relates to the fulfillment of material taxes, where every tax reporting should meet material requirements. Fulfilling the material requirements is related to taxpayer compliance, especially regarding the subject and tax object. In other words, taxpayers know what should be owed, if the debt is subject to the intangible taxable goods, then that is what has to be reported.

\subsection{Analysis of Administrative Sanctions Received by PT X regarding Tax Disputes due to Incorrect Payment of VAT Objects in the Form of Royalties in terms of the Ease of Administration Principle}

\subsubsection{Cause of Administrative Sanctions}

Utilization of royalties is one of the supporting goals of PT X's production, obtained by PT $\mathrm{X}$ from Japan because the desired needs of PT X indeed only come from that Japanese company. Utilization of royalties used by PT X to become an object of tax payable which is subsequently paid by PT X and can become a tax credit for PT X. Royalties are one of the objects of intangible taxable goods as stipulated in the explanation of Article 4 Paragraph (1) letter $g$ of the Law Number 42 Year 2009 about Value Added Tax of Goods and Services and Sales Tax on Luxury Goods, in this case the royalties used are included in the use or right to use copyrights in the field of literature, arts or scientific works, patents, designs or models, plans, formulas or confidential proceedings, trademarks or other forms of intellectual / industrial property rights or other similar rights. PT X uses royalties from outside the customs area in the field of design or special model for manual car transmission. Anthonius, Legal Counsel of PT X acknowledged that this tax dispute was purely the fault of PT X, an 
explanation of the errors that actually occurred due to administrative errors can be concluded that PT X's understanding of taxation is still considered lacking, which is referred to as lack of knowledge in taxation. Aside from administrative mistakes that were not intentionally made by PT X, the application of the overbooking that has been explained previously also cannot be done, although in fact if the overbook is done will avoid the administrative sanctions.

Administrative sanctions for PT X are calculated from the time the tax period was due in each month in 2015 to the Notice of Tax Underpayment Assessment issued in April 2017. The administrative sanctions imposed are based on Article 13 Paragraph (2) of the Law No. 28/2007 concerning General Provisions and Tax Procedures (UU KUP), which is an interest of $2 \%$ per month no longer than 24 months calculated from the time the tax becomes due or the end of the Tax Period until the issuance of the Notice of Tax Underpayment Assessment . From January 2015 to March 2015 the sanctions imposed were 2\% multiplied by a maximum of 24 months, i.e. $48 \%$ multiplied by taxes that were not or underpaid.

The following are details of the Underpayment Tax for the intangible taxable goods along with administrative sanctions.

Table 1. PT X 2015 Underpayment and Administrative Sanction Details (in Rupiah)

\begin{tabular}{|c|c|c|c|}
\hline \multirow[b]{2}{*}{ Type of Tax } & \multicolumn{2}{|c|}{ VAT-Input of Intangible Taxable Goods } & \multirow{2}{*}{$\begin{array}{c}\text { The Amount of Tax } \\
\text { Accrued }\end{array}$} \\
\hline & $\begin{array}{l}\text { Underpayment } \\
\text { Tax }\end{array}$ & Administrative Sancition & \\
\hline VAT January & $330,064,073$ & $158,430,755$ & $488,494,828$ \\
\hline VAT February & $277,228,417$ & $133,069,640$ & $410,298,057$ \\
\hline VAT March & $228,903,710$ & $109,873,781$ & $338,777,491$ \\
\hline VAT April & $227,163,722$ & $104,495,312$ & $331,659,034$ \\
\hline VAT May & $139,527,714$ & $61,392,194$ & $200,919,908$ \\
\hline VAT June & $336,535,142$ & $141,344,760$ & $477,879,902$ \\
\hline VAT July & $305,267,246$ & $122,106,898$ & $427,374,144$ \\
\hline VAT August & 768,656 & 292,089 & $1,060,745$ \\
\hline VAT September & $303,226,973$ & $109,161,710$ & $412,388,683$ \\
\hline VAT October & $209,275,599$ & $71,153,704$ & $280,429,303$ \\
\hline VAT November & $255,472,915$ & $81,751,333$ & $337,224,248$ \\
\hline VAT December & $264,491,978$ & $79,347,593$ & $343,839,571$ \\
\hline Total & $2,877,926,145$ & $1,172,419,770$ & $4,050,345,915$ \\
\hline
\end{tabular}

Source: processed from PT X data (2019)

In accordance with Article 6 Paragraph (1) Regulation of the Minister of Finance Number 40 / PMK.03 / 2010, the maximum due for these two objects is on the 15th of the following month, so that for the period of March 2015 to mature in April 15th, 2015. Whereas for the period of April 2015, due in May 15th, 2015, hence the calculations from April 2015 to December 2015 are calculated from the due date until the Notice of Tax Underpayment Assessment is issued in April 2017 (not a maximum of 24 months). The administrative sanctions received by PT X amounted to Rp1,172,419,770, so that when added to the tax base, the tax payable was $\mathrm{Rp} 4,050,345,915$. In carrying out its tax obligations, PT X always reports on time throughout year 2015 . 


\subsubsection{Administrative Sanctions received by PT X in terms of the Ease of Administration Principle}

Administrative sanctions obtained by PT X certainly cannot be detach and are automatically attached to PT X because the actions that have been recognized as PT X's own mistakes. Sanctions arising from the results of the false deposit must be paid back with the tax return process that should not have existed before, hence that causes delays. However, there are still principles in tax collection that must be prioritized in order to create harmony between taxpayers and the DGT. Administrative sanctions submitted to PT X make PT X tend to reject what is stated in the Objection Letter even though PT X acknowledged this was his mistake. PT $X$ believes that it was an unintentional mistake, so they raised an objection to this problem and argued that they should not accept the sanction. Besides there is no deliberate or intentional point, in the case of PT X there is no criminal element in the mistakes made by PT $\mathrm{X}$. Errors made by PT X with unintentional conditions and only because of mis recording of type of the deposit code, but unfortunately DGT seems to equate the actions of taxpayers who commit criminal elements. Administrative sanctions received by PT X can be related to the principle of ease of administration, where the tax collection system must not be separated from the principles that have been regulated.

1) Certainty

The existence of legal certainty is one of the principles of the ease of administration principle, where a clear regulation can facilitate taxpayers. A regulation must be clearly defined so that it does not cause many interpretations for the implementers of the regulations and taxpayers [7]. The measure of legal certainty can be seen through the subject, object, basis for taxation, tariffs and procedures. According to the Legal Counsel as the recipient of sanctions and the DGT as the sanctioner, administrative sanctions imposed on PT X when viewed from the principle of ease of administration, especially in terms of subject and object are in accordance with the law, there is a legal certainty that underlies that such mistakes will be subject to sanctions administration. Legal certainty measured through indicators in terms of procedures has not been reached because the 2015 tax dispute case occurred only in 2015 even though the same mistake had occurred in the previous tax years. However, those subject to examination and issued a Notice of Tax Underpayment Assessment are only for the 2015 tax year. In addition, in this case overbooking instruments cannot be used so that it is concerned with legal certainty in terms of procedures, hence PT X used a fairly complicated return instrument. Certainty as measured by the basic aspects of tax imposition and the rate received for administrative sanctions cannot be contested because it already exists in the legislation. This has been regulated in a law made by the Government, the duty of taxpayers is to comply with every regulation contained in the Act, especially regarding the basis for imposing taxes and tariffs on any administrative sanctions imposed for an error. In certainty principle, what has not been achieved is in terms of procedures while in the subject, object, tax base, and tariff the legal certainty has been achieved.

2) Convenience

Apart from the principle of certainty, there is a principle of convenience that is included in ease of administration principle. Comfort in taxation obligations related to the time of reporting or payment of tax should be at a pleasant time for taxpayers. The principle of convenience relates to how the tax is paid, when it must be paid and to the conditions how the taxpayer must pay the tax [8]. The principle of convenience if related to this dispute is related to the tax audit. The convenience of PT X when being billed back in taxes according to the Examiner is underpaid, becomes less. As explained by the Legal Counsel of PT X before, that the use of royalties is purely for business processes. Likewise, with a clear and uncertain 
financial turnaround as planned by PT X, is needed by PT X for PT X's business processes going forward. PT X, who made an accidental deposit, certainly did not think that there was underpayment of royalties because PT X had made its tax obligations on time. For PT X, the principle of convenience will arise if the deposit error that has occurred can be processed with regulations that can support PT X's financial turnover, bearing in mind that the business processes carried out by PT X are very influential for the preservation of production produced by PT X. The Legal Counsel of PT X explains that there is no preparation in the form of provision for funds for administrative sanctions, especially for the types of taxes that have been reported on time. Without the provision of funds or budgeting for these sanctions will certainly have an impact on PT X's cash flow. Aside from that, the imposition of administrative sanctions will have an impact on the responsibility that will be given by PT X to the company. Therefore, administrative sanctions imposed on PT X seen from ease of administration principle do not meet the principle of convenience.

3) Efficiency

There is the principle of efficiency, where this principle puts forward a good taxation system, it must be easy to administer and easy to obey. Fulfillment of this principle of efficiency includes the costs of calculation, billing and tax supervision must be as low as possible. This principle of efficiency must be met by the Government and also the Taxpayer. Fedriyan as Head of the Appeals and Lawsuit Section, explained the administrative costs used to collect administrative sanctions from PT X, which were considered efficient because they spent less than the tax receipts originating from PT X. He also added that each tax collection was efficient in terms of administrative costs because the expenditure is only $2-3 \%$ of the realization of tax revenue. In the case of a rule it is said to be efficient if the costs incurred by the Government are somewhat smaller than the costs incurred for billing. The efficiency according to taxpayers is measured through administrative sanctions received by PT X, compliance cost, which is the administrative burden that must be borne by taxpayers to carry out their tax obligations. Compliance costs are divided into 3 namely fiscal costs, time costs, and psychology costs. Those 3 aspects of compliance were not fulfilled because PT X had to pay administrative sanctions for a long period of time and made PT X depressed.

4) Simplicity

According to Sommerfield, a good tax administration is a tax administration that adheres to the principle of simplicity because it will make it easier for taxpayers and tax officials to calculate, collect and administer tax owed [4]. Errors in this case only occur in writing or administration errors and do not cause changes to the substance that there should be no convoluted process to make changes, which in this case is the type of deposit code. The flow to reduce the burden of administrative sanctions is also a long and complex path. This lack of simplicity will make PT X in the future choose not to comply at all for the sake of PT X's production process running smoothly.

Based on the ease of administration principle theory, it can be concluded that the imposition of administrative sanctions on PT X is in accordance with the certainty principle when viewed based on the object, subject, basis of taxation and tariffs because all of them are already attached in the Law determined by the Government. However, when viewed from a procedural point of view, it is not yet in accordance with certainty principles because there is still a regulatory vacuum in the case of PT X. Furthermore, the imposition of administrative sanctions does not meet the principle of convenience because it is not at the right time for PT $\mathrm{X}$ and does not create comfort for PT X. In addition, administrative sanctions imposed on PT $\mathrm{X}$ have fulfilled the principle of efficiency when viewed from the Government's side but have not met the efficiency principle when viewed from the Taxpayer's side because PT X will add 
to the burden of resolving disputes related to tax obligations that are incorrectly deposited. Finally, administrative sanctions do not meet the principle of simplicity because the process that must be passed by PT X related to the settlement of administrative sanctions is not easy to implement and is still complex.

\section{Conclusion}

1. The basis of considerations of the DGT makes regulations for the utilization of Intangible Taxable Goods and Taxable Services from Outside the Customs Territory, which cannot be done with overbook because both objects are objects that are difficult to detect and can be objects for tax avoidance, ownership of documentary evidence is actually a foreign party while the person who is supposed to make a transfer request is the owner of the document evidence, and the tax that has been deposited has become a tax credit and will not move to another place other than the state treasury because the tax credit is the taxpayer's right. Considerations taken by DGT have not met the theory of good tax administration because there has been no legal formulation related to this matter and DGT's accountability is still considered to be lacking in terms of supervision and control.

2. Administrative sanctions received by PT X due to tax deposit errors are not in accordance with the ease of administration principle, except for certainty principle indicators that are seen in terms of subject, object, tax base, and tariff. The four aspects are in accordance with the certainty principle because it is regulated in the Act, but the procedure is not in accordance with the certainty principle because there is no regulation that governs this case if it occurs and is detrimental to the Taxpayer. In addition, the principle of convenience is not fulfilled because the inspection is carried out so long that administrative sanctions increase and disrupt cash flow for business activities carried out by PT X. The principle of efficiency is met on the Government's side, namely administrative costs in tax collection, the amount of the cost is lower than the tax revenue received country. However it is not fulfilled in terms of taxpayers or compliance costs, because of the three aspects of the principle of efficiency is not met; fiscal cost where PT $\mathrm{X}$ has to pay sanctions for inadvertence, time cost because a lot of time is wasted for PT $\mathrm{X}$, and psychological cost which makes PT X indifference the principle of simplicity not fulfilled because administrative sanctions arise due to regulations from book-entry which cannot be done so that PT $\mathrm{X}$ have to go through many procedures for the sake of resolving tax disputes because of accidental tax payments.

\section{References}

[1] Sutedi, A. (2014). Hukum Ekspor Impor. Jakarta: Raih Asa Sukses.

[2] Darussalam, D. S. (2018). Konsep dan Studi Komparasi Pajak Pertambahan Nilai . Jakarta: DDTC.

[3] Sukardji, U. (2015). Pajak Pertambahan Nilai Edisi Revisi 2015. Jakarta: Rajawali.

[4] Haula Rosdiana, D. E. (2012). Pengantar Ilmu Pajak. Jakarta: PT RajaGrafindo Jakarta.

[5] Clinton Alley, D. B. (2005). A Remodelling of Adam Smith's Tax Design Principles. Australian Tax Forum, 578-624. 
[6] Simon James, A. S. (2016). The Complexity of Tax Simplification. New York: Palgrave Macmillan.

[7] Soemitro. (1988). Pajak Ditinjau dari Segi Hukum. Bandung: PT Eresco Bandung.

[8] Nurmantu. (1994). Dasar-Dasar Perpajakan. Jakarta: IND-HILL-CO Jakarta.

[9] Minister of Finance Republik Indonesia. (2010, Februari 22). Regulation of the Minister of Finance Number 40 / PMK.03 / 2010 concerning Procedures for Calculating, Collecting, Depositing and Reporting Value Added Tax on Utilization of Intangible Taxable Goods and / or Taxable Services from Outside the Customs Territory.

[10] (2014, Desember 24). Minister of Finance Regulation PMK 242 / PMK.03 / 2014 concerning Procedures for Payment and Depositing Taxes.

Republik Indonesia. (2007). Law Number 28 of 2007 concerning General Provisions and Tax [11] Procedures .

(2009). Law Number 42 of 2009 concerning Value Added Tax of Goods and Services

[12] and Sales Tax on Luxury Goods. 